University of Nebraska - Lincoln

DigitalCommons@University of Nebraska - Lincoln

Faculty Publications: Department of Entomology

Entomology, Department of

December 1998

\title{
Parasitism of Greenbugs (Homoptera: Aphididae) by Lysiphlebus testaceipes (Hymenoptera: Braconidae) in Grain Sorghum: Implications for Augmentative Biological Control
}

\author{
Odair A. Fernandes \\ University of Nebraska-Lincoln, oafernandes@fcav.unesp.br \\ Robert J. Wright \\ University of Nebraska-Lincoln, rwright2@unl.edu \\ Z. B. Mayo \\ Univesity of Nebraska - Lincoln, zmayo1@unl.edu
}

Follow this and additional works at: https://digitalcommons.unl.edu/entomologyfacpub

Part of the Entomology Commons

Fernandes, Odair A.; Wright, Robert J.; and Mayo, Z. B., "Parasitism of Greenbugs (Homoptera: Aphididae) by Lysiphlebus testaceipes (Hymenoptera: Braconidae) in Grain Sorghum: Implications for Augmentative Biological Control" (1998). Faculty Publications: Department of Entomology. 102.

https://digitalcommons.unl.edu/entomologyfacpub/102

This Article is brought to you for free and open access by the Entomology, Department of at DigitalCommons@University of Nebraska - Lincoln. It has been accepted for inclusion in Faculty Publications: Department of Entomology by an authorized administrator of DigitalCommons@University of Nebraska - Lincoln. 


\title{
Parasitism of Greenbugs (Homoptera: Aphididae) by Lysiphlebus testaceipes (Hymenoptera: Braconidae) in Grain Sorghum: Implications for Augmentative Biological Control
}

\author{
ODAIR A. FERNANDES, ${ }^{1}$ ROBERT J. WRIGHT, ${ }^{2}$ aNd Z B MAYO
}

Department of Entomology, University of Nebraska-Lincoln, Lincoln NE 68583-0816

\begin{abstract}
J. Econ. Entomol. 91 (6): 1315-1319 (1998)
ABSTRACT Field cage studies were conducted to describe the relationship between the percentage of Lysiphlebus testaceipes (Cresson) parasitism (as measured by aphid mummies) and densities of greenbug, Schizaphis graminum Rondani, on grain sorghum, Sorghum bicolor L. In 1993 and 1994, a biotype E-susceptible grain sorghum hybrid was grown in field cages and $L$. testaceipes adults were released after each plant was infested with 20 biotype $\mathrm{E}$ greenbugs. The release rates were $0,0.5,1.0$, and 2.0 wasps per plant in 1993, and $0,0.16,0.33$, and 0.5 wasps per plant in 1994 . Greenbugs and mummies were counted 1-2 times a week on all leaves of 2-4 randomly selected plants per cage. A release rate of $0.33-0.5$ wasps per plant infested with 20 greenbugs maximized the number of mummies produced and prevented the greenbugs from reaching an economic threshold of 1,000 greenbugs per plant. Peak numbers of mummies occurred $\approx 400-500 \mathrm{DD}\left(10^{\circ} \mathrm{C}\right.$ base $)$ after the initial wasp release. Regression analyses showed that the greenbug population started decreasing when the percentage of parasitism (as measured by mummies) reached $20-30 \%$. Greenbugs in the absence of wasps significantly reduced yield in 1994, but not in 1993.
\end{abstract}

KEY WORDS biological control, parasitoids, greenbugs, augmentation, grain sorghum

SINCE ITS FIRST appearance as a pest of grain sorghum, Sorghum bicolor L., in 1968 (Harvey and Hackerott 1969), several methods have been developed to control greenbugs, Schizaphis graminum Rondani. Plant resistance and insecticides have been the most commonly used control tactics. However, greenbugs have continued to adapt to these tactics. New greenbug biotypes such as $\mathrm{E}$ and $\mathrm{I}$ have developed during the past few decades (Michels et al. 1987, Harvey et al. 1991). These new biotypes threaten the production of sorghum and other cereals. In addition, development of greenbug strains with resistance to organophosphate insecticides also has been reported (Shotkoski et al. 1990, Sloderbeck et al. 1991, Wilde et al. 1993).

The braconid parasitoid Lysiphlebus testaceipes (Cresson) is considered to be one of the most important biological control agents of greenbugs (Jackson et al. 1970). Females lay eggs in the aphids, which become mummies in 7-10 d (Hight et al. 1972). Mummies are $\tan$ in color and are easily observed in the field. Lysiphlebus testaceipes mummies can be identified through the presence of a rounded emergence hole, an operculum, and elongate meconial pellets (Johnson et al. 1979). This wasp is not thought to overwinter in the northern states, and it likely dis-

\footnotetext{
${ }^{1}$ Current address: Department of Entomology and Nematology, FCAVJ/UNESP, 14870-000, Jaboticabal SP, Brazil.

${ }^{2}$ Mailing address: South Central Research \& Extension Center, Box 66, Clay Center NE 68933. To whom reprint requests should be sent.
}

perses each spring within parasitized winged aphids that migrate northward (Jackson et al. 1970).

Greenbug population regulation by $L$. testaceipes was modeled by Knipling and Gilmore (1971). In their simulation, 6,500 wasps per hectare released during the 2nd greenbug generation (at 2 greenbugs per plant) was the most efficient rate to keep the pest population under regulation. However, in a caged sorghum study conducted by Starks et al. (1974), wasps released at this rate did not control greenbugs effectively. Starks et al. (1974) suggested that the wasp might not be as effective in the field as it was in the laboratory.

Greenbugs migrate from southern states during the spring (Kieckhefer et al. 1974, Kring and Kring 1990) and can reach high densities after migratory flights. Heavy infestations may require insecticide applications. An alternative approach would be the use of augmentative biological control with $L$. testaceipes. Large numbers of $L$. testaceipes could be produced in greenbug-susceptible sorghum strips and allowed to disperse throughout the field. Preliminary field studies in 1991 and 1992 by Fernandes (1995) demonstrated the potential of this approach. Augmentative biological control of greenbugs would be an alternative management practice that could lessen current problems of resistance of greenbugs to insecticides and development of new biotypes.

The objectives of this research were to develop baseline information on L. testaceipes-greenbug relationships to contribute to the development of parasi- 
toid augmentation procedures, including optimum wasp-host ratios for production of wasps, and the relationship between wasp release rates and greenbug population growth and damage.

\section{Materials and Methods}

In 1993 and 1994, 4 strips of 4 rows each of a biotype Egreenbug-susceptible sorghum (Funk 522 DR) were planted within a nonirrigated 2.4-ha field of biotype $\mathbf{E}$ greenbug-resistant hybrid (Funk $550 \mathrm{E}$ ) sorghum at the University of Nebraska South Central Research \& Extension Center, Clay Center, NE. The susceptible hybrid strips ran the length of the field and were $\approx 50$ $\mathrm{m}$ apart from each other. Planting dates for both the resistant and susceptible hybrids were 27 May 1993 and 24 May 1994. Four $8-\mathrm{m}^{3}$ saran fabric (32 by 32 mesh) cages (Bioquip, Gardena, CA), were placed in each strip immediately after plant emergence. Cages were $\approx 5 \mathrm{~m}$ apart in the strip. Each cage contained 24 plants.

After reaching stage 5 (Vanderlip 1972), each plant was infested with 20 biotype $\mathrm{E}$ greenbugs reared in a field cage for 3-4 wk on biotype E-susceptible sorghum. Greenbugs were confined on plants using leaf cages made of 1 -sided adhesive mounting foam (Lundell, Minneapolis, MN) rectangles ( 80 by 25 by $6 \mathrm{~mm}$ ) with an opening ( 37 by $12 \mathrm{~mm}$ ) covered with muslin. Leaf cages were clipped on the 7th or 8th leaf from the bottom of sorghum plants in the field cages. The leaf cages were removed $2-3 \mathrm{~d}$ after greenbug introduction.

Adult wasps were released immediately after leaf cage removal. Wasps reared in the field on greenbuginfested caged sorghum were sorted by sex (1/3.5 $\delta / 9$ ratio) and transferred to $20-\mathrm{ml}$ glass vials. Open vials with adult wasps were left in the center of each cage to allow wasp release.

A $4 \times 4$ Latin square experimental design was used. Treatments consisted of 3 wasp rates and a no wasp check, replicated 4 times. The release rates were 0.5 , 1.0 , and 2.0 adult wasps per infested plant in 1993 . Based on 1993 results, lower wasp release rates $(0.16$, 0.33 , and 0.5 adult wasps per infested plant) were used in 1994. These represented $36,000,72,000$, and 144,000 and $12,000,24,000$, and 36,000 wasps per hectare infested with 1,440,000 greenbugs per hectare in 1993 and 1994, respectively.

Sampling was conducted once or twice a week. All greenbugs and mummies, with or without emergence holes, were counted on all leaves of 2-4 randomly selected plants per cage. Only mummies without exit holes were included in the data analyses. Initially, when numbers of insects were low, 4 plants were sampled. However, when greenbug densities increased, the sample size was reduced to 2 plants per cage. Sampling continued until plants in the check were dead. Sorghum grain in each cage was hand harvested at maturity, dried $\left(38^{\circ} \mathrm{C}\right.$ for $\left.48 \mathrm{~h}\right)$, and weighed.

Data analysis. Sampling dates were converted to degree-days (DD) accumulated from the greenbug

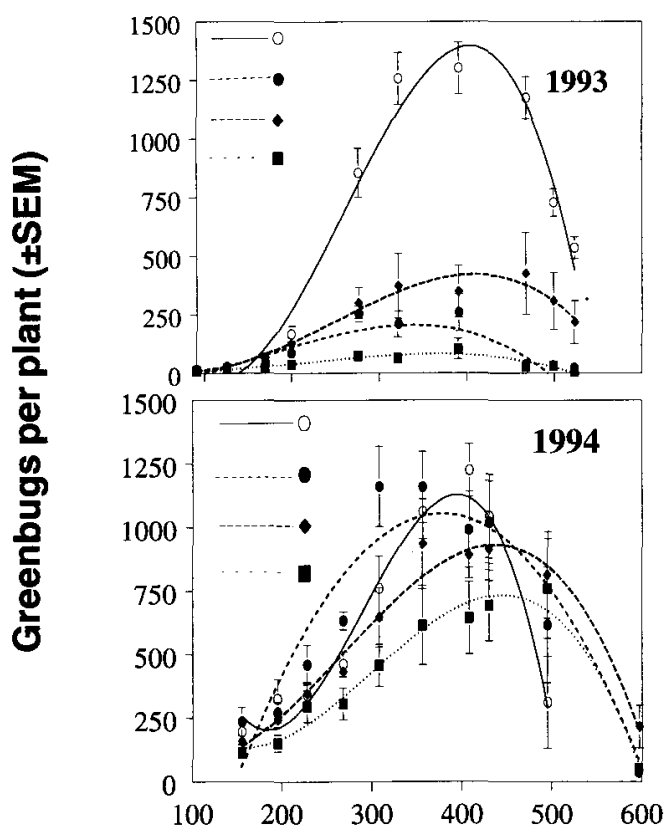

Celsius DD (>10 C)

Fig. 1. Density of greenbugs in field cages with different L. testaceipes release rates in relation to degree-day accumulations $\left(10^{\circ} \mathrm{C}\right.$ base $)$. $1993 ; 0,0$ wasp per plant;, 0.5 wasp per plant; $\diamond, 1$ wasp per plant; $\mathbf{\square}, 2$ wasps per plant. 1994: $\bigcirc, 0$ wasp per plant; 0.16 wasp per plant; $\diamond, 0.33$ wasp per plant; $\square, 0.5$ wasp per plant.

infestation date using the half-day sinewave method (Higley et al. 1986) with a $10^{\circ} \mathrm{C}$ base. The relationships between number of greenbugs, percentage of parasitism, and degree-days were described by polynomial regression (SAS Institute 1990) with $P=0.10$. The relationship between yield and wasp release rates was tested by linear regression (SAS Institute 1990) with $P=0.05$.

\section{Results and Discussion}

The density of greenbugs in the treatment without wasps increased and exceeded the economic threshold level of 1,000 greenbugs per plant (Teetes 1994) during both years (Fig. 1). In 1993, the treatment with 2 wasps released per plant resulted in the lowest greenbug density, although none of the treatments with wasps reached the economic threshold (Fig. 1). In 1994, as few as 0.33 wasps per plant initially were able to maintain greenbug densities at levels below the economic threshold.

In both years, the greenbug densities started decreasing at $\approx 400$ DD after the wasp release (Fig. 1). These results appear to be similar to those obtained by Starks et al. (1974). Although Starks et al. (1974) did not refer to physiological time, they observed reduction in the greenbug population after $4 \mathrm{wk}$. In 1993 and $1994,400 \mathrm{DD}$ corresponded to $\approx 29$ and $31 \mathrm{~d}$, respectively. 
Polynomial regression of the mean number of mummies observed per plant against physiological time (Fig. 2) showed that for both years, a release rate between 0.33 and 0.50 wasps per plant infested with 20 greenbugs maximized the number of mummies produced. Peak numbers of mummies occurred at $\approx 400$ 500 DD after the initial wasp release in both years. These initial parasitoid levels also prevented the greenbug population from reaching the economic threshold level (Fig. 1).

The relationship between percentage of parasitism (as measured by L. testaceipes mummies) and total number of greenbugs present on plants (Fig. 3) usually was quadratic (Table 1) and showed that for all wasp release rates when percentage of parasitism reached $\approx 30 \%$ (1993) or $20 \%$ (1994), the greenbug densities declined. In 1993, only the rate of 0.5 wasp per plant resulted in a significant regression (Table 1 ).

The relationship between number of mummies and greenbugs showed that greenbug densities increased rapidly up to $10 \%$ mummies but slowed beyond this level, and then declined, regardless of the number of wasps initially released (Fig. 3). Similar trends also were observed in field studies conducted using borders planted with mixed greenbug-resistant and susceptible hybrids (Fernandes 1995).

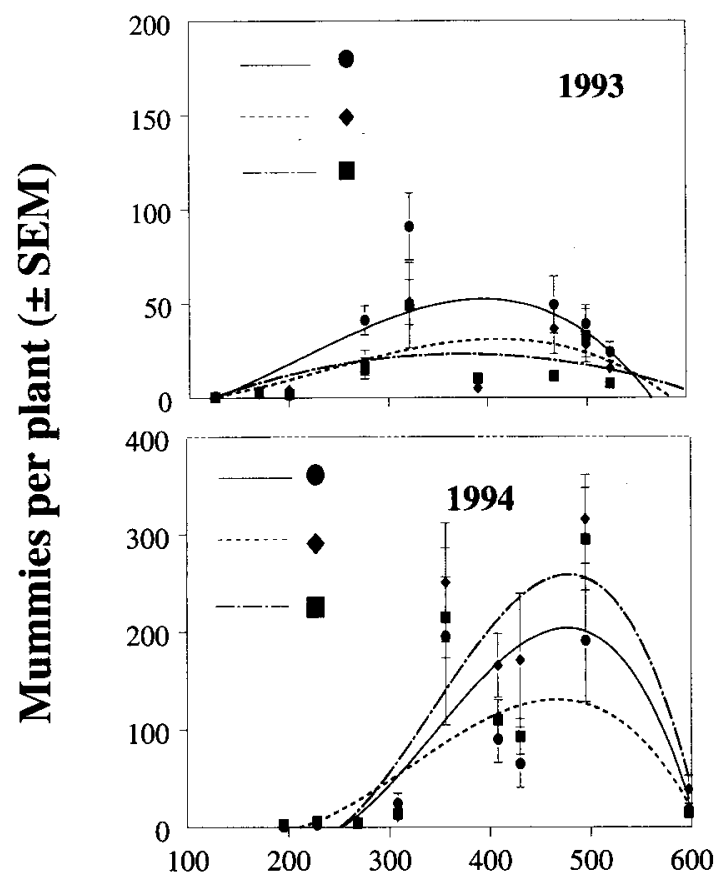

\section{Celsius DD $>10 \mathrm{C}$}

Fig. 2. Density of L. testaceipes mummies in field cages with different $L$. testaceipes release rates in relation to degree-day accumulations $\left(10^{\circ} \mathrm{C}\right.$ base). 1993: 0.5 wasp per plant; $\diamond, 1$ wasp per plant; $\mathbf{D}, 2$ wasps per plant. $1994 ; 0,0.16$ wasp per plant; $\bullet, 0.33$ wasp per plant; $\mathbf{\square}, 0.5$ wasp per plant.

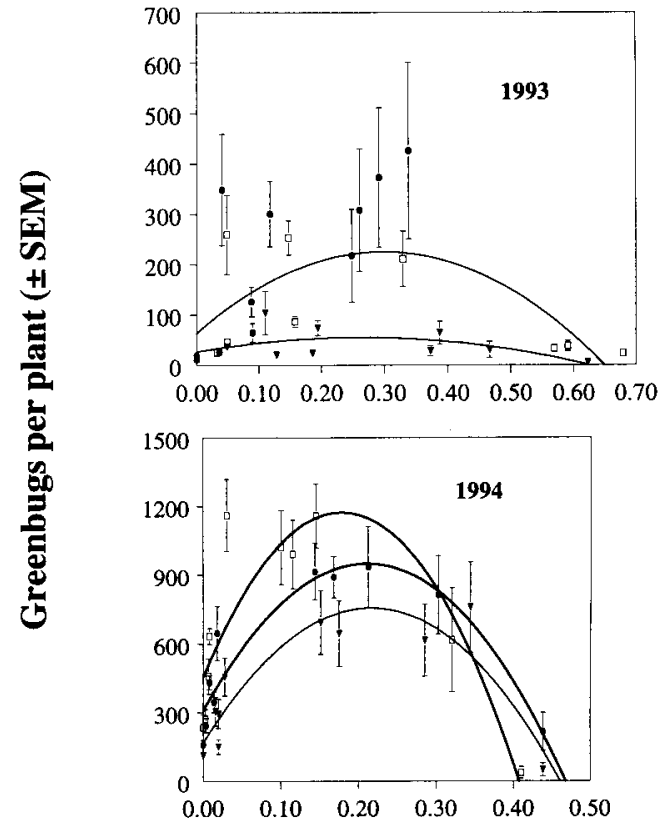

\section{Proportion of parasitism}

Fig. 3. Relationship between proportion of $L$. testaceipes parasitism (mummies) and greenbug density in field cages. 1993: $\square, 0.5$ wasp per plant; , 1 wasp per plant; $\mathbf{\nabla}, 2$ wasps per plant. 1994: $\square, 0.16$ wasp per plant;, 0.33 wasp per plant; $\nabla, 0.5$ wasp per plant.

Hight et al. (1972) reported that the number of offspring produced by parasitized greenbugs is much lower than that by unparasitized greenbugs. Moreover, they observed that lst instars do not reach reproductive maturity if parasitized. This decrease in greenbug reproduction when parasitized would explain the relationship of percentage of mummies to the greenbug densities observed in our field cage studies. These results confirm the recommended guidelines for greenbug management in Nebraska (Wright et al. 1994), which suggest that control is not needed if the percentage of mummies is $\geq 20 \%$.

The percentage of mummies underestimates parasitism because counting mummies excludes parasitized greenbugs not yet visible as mummies. However, from a practical perspective, mummies are the easiest indicator of parasitism to observe in the field. The percentage of mummies is a simple practical index of greenbug parasitism by $L$. testaceipes. Mackauer and Chow (1986) did not recommend the use of mummies to assess the impact of parasitoids, because mummies accumulate over time. To avoid this problem, in our cage studies only mummies without emergence holes were included in the analyses. This distinction is readily observable in the field and allows assessment of newly parasitized aphids if sampling is conducted on a regular basis.

There was no significant linear relationship between sorghum yields and wasp release rates during 
Table 1. Regression statistics describing data presented in Figs. 1-4

\begin{tabular}{|c|c|c|c|c|c|c|c|c|c|}
\hline $\begin{array}{l}\text { Treatment, } \\
\text { wasps/plant }\end{array}$ & a & & b & c & d & $\mathbf{R}_{2}$ & $F$ & df & $P$ \\
\hline \multicolumn{10}{|c|}{ Fig. 1: Greenbugs per plant as a function of degree days, 1993} \\
\hline $\begin{array}{l}0 \\
0.5 \\
1 \\
2\end{array}$ & $\begin{array}{r}844.58 \\
-65.37 \\
105.84 \\
22.64\end{array}$ & $\begin{array}{r}-16 \\
0 \\
-2 \\
-0\end{array}$ & $\begin{array}{l}.73 \\
.17 \\
.47 \\
.43\end{array}$ & $\begin{array}{c}0.09 \\
6.13 \times 10^{-3} \\
1.78 \times 10^{-2} \\
3.69 \times 10^{-3}\end{array}$ & $\begin{array}{r}1.2 \times 10^{-4} \\
-1.21 \times 10^{-5} \\
-2.41 \times 10^{-5} \\
5.65 \times 10^{-6}\end{array}$ & $\begin{array}{l}0.91 \\
0.53 \\
0.25 \\
0.32\end{array}$ & $\begin{array}{r}126.8 \\
13.5 \\
4.0 \\
5.6\end{array}$ & $\begin{array}{l}3,36 \\
3,36 \\
3,36 \\
3,36\end{array}$ & $\begin{array}{l}0.0001 \\
0.0001 \\
0.0145 \\
0.0030\end{array}$ \\
\hline \multicolumn{10}{|c|}{ Fig. 1: Greenbugs per plant as a function of degree days, 1994} \\
\hline $\begin{array}{l}0 \\
0.16 \\
0.33 \\
0.5\end{array}$ & $\begin{array}{r}3,533.65 \\
-1,821.85 \\
324.23 \\
860.36\end{array}$ & $\begin{array}{r}-42 \\
15 \\
-5 \\
-10\end{array}$ & $\begin{array}{l}.98 \\
.25 \\
.54 \\
.50\end{array}$ & $\begin{array}{c}0.17 \\
-2.02 \times 10^{-2} \\
3.48 \times 10^{-2} \\
4.53 \times 10^{-2}\end{array}$ & $\begin{array}{c}-1.98 \times 10^{-4} \\
- \\
-4.33 \times 10^{-5} \\
-5.01 \times 10^{-5}\end{array}$ & $\begin{array}{l}0.79 \\
0.55 \\
0.60 \\
0.45\end{array}$ & $\begin{array}{r}37.2 \\
20.0 \\
17.8 \\
9.6\end{array}$ & $\begin{array}{l}3,30 \\
2,33 \\
3,35 \\
3,36\end{array}$ & $\begin{array}{l}0.0001 \\
0.0001 \\
0.0001 \\
0.0001\end{array}$ \\
\hline \multicolumn{10}{|c|}{ Fig. 2: Mummies per plant as a function of degree days, 1993} \\
\hline $\begin{array}{l}0.5 \\
1 \\
2\end{array}$ & $\begin{array}{r}-11.33 \\
-1.60 \\
-28.12\end{array}$ & $\begin{array}{r}-6 \\
-8 \\
0\end{array}$ & $\begin{array}{l}.72 \times 10^{-2} \\
.57 \times 10^{-2} \\
.27\end{array}$ & $\begin{array}{r}1.56 \times 10^{-3} \\
9.95 \times 10^{-4} \\
-3.68 \times 10^{-4}\end{array}$ & $\begin{array}{c}-2.49 \times 10^{-6} \\
-1.44 \times 10^{-6} \\
-\end{array}$ & $\begin{array}{l}0.32 \\
0.25 \\
0.14\end{array}$ & $\begin{array}{l}5.7 \\
4.1 \\
2.9\end{array}$ & $\begin{array}{l}3,36 \\
3,36 \\
2,37\end{array}$ & $\begin{array}{l}0.0027 \\
0.0139 \\
0.0680\end{array}$ \\
\hline \multicolumn{10}{|c|}{ Fig. 2: Mummies per plant as a function of degree days, 1994} \\
\hline 0.16 & 198.89 & -2 & .68 & $1.06 \times 10^{-2}$ & $-1.10 \times 10^{-5}$ & 0.26 & 3.7 & 3,32 & 0.0210 \\
\hline \multicolumn{9}{|c|}{ Fig. 2: Mummies per plant as a function of degree days, 1994} & 0.0001 \\
\hline \multicolumn{10}{|c|}{ Fig. 2: Mummies per plant as a function of degree days, 1994} \\
\hline \multicolumn{10}{|c|}{ Fig. 3: Greenbugs per plant as function of proportion of greenbugs parasitized, 1993} \\
\hline 0.5 & 63.77 & $1,082$. & & $-1,816.94$ & - & 0.49 & 3.4 & 2,27 & 0.095 \\
\hline \multicolumn{10}{|c|}{ Fig. 3: Greenbugs per plant as function of proportion of greenbugs parasitized, 1994} \\
\hline $\begin{array}{l}0.16 \\
0.33 \\
0.5\end{array}$ & $\begin{array}{l}168.82 \\
458.22 \\
310.79\end{array}$ & $\begin{array}{l}5,433 . \\
8,007 . \\
6,052\end{array}$ & & $\begin{array}{l}-1,2593 \\
-2,2420 \\
-1,4357\end{array}$ & $\begin{array}{l}- \\
-\end{array}$ & $\begin{array}{l}0.82 \\
0.76 \\
0.89\end{array}$ & $\begin{array}{l}16.2 \\
11.0 \\
29.6\end{array}$ & $\begin{array}{l}2,27 \\
2,7 \\
2,7\end{array}$ & $\begin{array}{l}0.0024 \\
0.007 \\
0.0004\end{array}$ \\
\hline \multicolumn{10}{|c|}{ Fig. 4: Grain yield as a function of parasitoid release rate } \\
\hline
\end{tabular}

Regression: $Y=a+b x+c x^{2}+d x^{3}$.

1993 (Fig. 4). However, there was a significant linear regression of yields and wasp release rates in 1994 (Table 1); yields increased with increasing wasp release rates (Fig. 4). One difference between the 2 yr is that higher than normal precipitation occurred in 1993 (Fernandes 1995); thus, yield might not have been as influenced by greenbug feeding because of reduced water stress.

Implications for pest management The greatest $L$. testaceipes mummy production occurred when 0.33 0.50 wasps were released per plant initially infested with 20 greenbugs. These parasitoid release rates in cages also were able to keep greenbug densities below the economic threshold. These wasp rates are higher on a per-plant basis than the rates used by Starks et al. (1974) in similar experiments ( 0.033 wasps per plant). However, they had lower initial greenbug densities (2 per plant), resulting in similar greenbug/parasitoid ratios in the 2 studies. In contrast to results obtained by Starks et al. (1974), this parasitoid was very effective in controlling greenbug at the release rates used in this study.

The rearing and release of $24,000-36,000$ wasps per hectare (0.33-0.50 wasps per plant) may not be economically feasible in an inundative biological control program. However, the use of greenbug nurseries (planting of susceptible sorghum hybrids in strips) for an inoculative parasitoid augmentation program might be a more practical way to economically produce these numbers of wasps. Peak numbers of mummies could be expected to occur $\approx 450-500 \mathrm{DD}$ after the initial wasp release, and wasp emergence would occur soon thereafter. Establishment of the field nurseries would have to occur before the expected period of greenbug infestation, which varies from year to year.

These studies have documented that $L$. testaceipes can maintain greenbug densities below an economic threshold, if introduced early enough in relation to greenbug population dynamics. Although Fernandes et al. (1997) documented in 1 field study that $L$. testaceipes can move up to $50 \mathrm{~m}$ in $48 \mathrm{~h}$ within a sorghum field, additional information on dispersal behavior of $L$. testaceipes within sorghum fields is needed to determine the best spatial arrangement of $L$. testaceipes nurseries within a sorghum field to provide reliable biological control of greenbugs.

\section{Acknowledgments}

We thank Terry DeVries and Jason Bondegard (University of Nebraska-Lincoln, South Central Research \& Extension Center) for assistance with the field studies at Clay Center, 

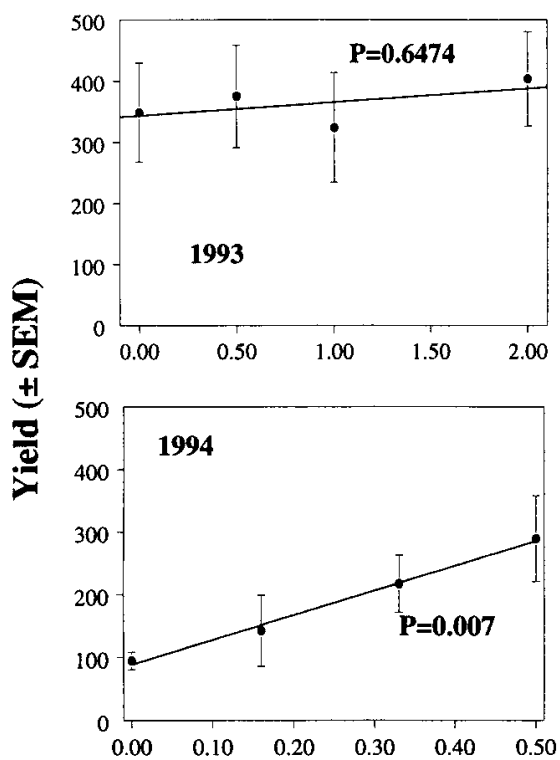

\section{Parasitoids per plant}

Fig. 4. Relationship between $L$. testaceipes release rates and grain sorghum yield $\left(\mathrm{g} / \mathrm{m}^{2}\right)$. Twenty greenbugs per plant were added before parasitoids were released in field cages.

and E. A. Heinrichs and F. P. Baxendale (University of Nebraska-Lincoln) for reviewing the manuscript. This research was supported in part by University of Nebraska Agricultural Experiment Station Project Nos. 48-022 and 17-070. Odair Fernandes was supported by an assistantship from Fundação de Amparo - Pesquisa do Estado de São Paulo (FAPESP). This paper is Journal Series No. 12052 of the Agricultural Research Division, University of Nebraska and Contribution No. 966 of the Department of Entomology, University of Nebraska-Lincoln.

\section{References Cited}

Fernandes, Odair A. 1995. Population dynamics and spatial distribution of Lysiphlebus testaceipes (Cresson) (Hymenoptera: Braconidae) and its host, the greenbug, Schizaphis graminum Rondani (Homoptera: Aphididae): studies for the development of an augmentation program. Ph. D. dissertation, University of Nebraska, Lincoln.

Fernandes, O. A., R. J. Wright, K. H. Baumgarten, and Z B Mayo. 1997. Use of rubidium to label Lysiphlebus testaceipes (Cresson) (Hymenoptera: Braconidae), a parasitoid of greenbugs (Homoptera: Aphididae), for dispersal studies. Environ. Entomol. 26: 1167-1172.

Harvey, T. L., and H. L. Hackerott. 1969. Recognition of a greenbug biotype injurious to sorghum. J. Econ. Entomol. 62: 776-779.

Harvey, T. L., K. D. Kofoid, T. J. Martin, and P. E. Sloderbeck. 1991. A new greenbug virulent to E-biotype resistant sorghum. Crop. Sci. 31: 1689-1691.

Hight, S. C., R. D. Eikenbary, R. J. Miller, and K. J. Starks. 1972. The greenbug and Lysiphlebus testaceipes. Environ. Entomol. 1: 205-209.
Higley, L. G., L. P. Pedigo, and K. R. Ostlie. 1986. DEGDAY: a program for calculating degree-days, and assumptions behind the degree-day approach. Environ. Entomol. 15: 999-1016.

Jackson, H. B., L. W. Coles, E. A. Wood, Jr., and R. D. Eikenbary. 1970. Parasites reared from the greenbug and corn leaf aphid in Oklahoma in 1968 and 1969. J. Econ. Entomol. 63: 733-736.

Johnson, J. W., R. D. Eikenbary, and D. Holbert. 1979. Parasites of the greenbug and other graminaceous aphids: identity based on larval meconia and features of the empty aphid mummy. Ann. Entomol. Soc. Am. 72: 759-766.

Kieckhefer, R. W., W. F. Lytle, and W. Spuhler. 1974. Spring movement of cereal aphids into South Dakota. Environ. Entomol. 3: 347-350

Knipling, E. F., and J. E. Gilmore. 1971. Population density relationships between hymenopterous parasites and their aphids hosts-a theoretical study. U. S. Dep. Agric. Tech. Bull. 1428.

Kring, J. B., and T. J. Kring. 1990. Aphid flight behavior, pp. 203-214. In D. C. Peters, J. A. Webster, and C. S. Chlouber [eds.], Aphid-plant interactions: populations to molecules. MP-132. Agricultural Experiment Station, Oklahoma State University, Stillwater.

Mackauer, M., and F. J. Chow. 1986. Parasites and parasite impact on aphid populations, pp. 95-118. In G. D. McLean, R. G. Garret, and W. G. Ruesink [eds.], Plant virus epidemics: monitoring, modeling and predicting outbreaks. Academic. Sydney.

Michels, G. J., Jr., T. J. Kring, R. W. Behle, A. C. Bateman, and N. M. Heiss. 1987. Development of greenbug (Homoptera: Aphididae) on corn: geographic variations in host-plant range of biotype E. J. Econ. Entomol. 80: 394-397.

SAS Institute. 1990. SAS/STAT user's guide, vol. 1, release 6.03. SAS Institute, Cary, NC.

Shotkoski, F. A., Z B Mayo, and L. L. Peters. 1990. Induced disulfoton resistance in greenbugs (Homoptera: Aphididae). J. Econ. Entomol. 83: 2147-2152.

Sloderbeck, P. E., M. A. Chowdhury, L. J. DePew, and L. L. Buschman. 1991. Greenbug (Homoptera: Aphididae) resistance to parathion and chlorpyrifos-methyl. J. Kans. Entomol. Soc. 64: 1-4.

Starks, K. J., E. A. Wood, Jr., and R. L. Burton. 1974. Relationship of plant resistance and Lysiphlebus testaceipes to populations levels of the greenbug on grain sorghum. Environ. Entomol. 3: 950-952.

Teetes, G. L. 1994. Adjusting crop management recommendations for insect-resistant crop varieties. J. Agric. Entomol. 11: 191-200.

Vanderlip, R. L. 1972. How a sorghum plant develops. Cooperative Extension Service, Kansas State University, Manhattan.

Wilde, G., R. Shufran, and R. Bowling. 1993. Insecticide resistance among biotype I greenbugs (Homoptera: Aphididae). J. Kans. Entomol. Soc. 66: 453-454.

Wright, R. J., S. D. Danielson, J. F. Witkowski, G. L. Hein, J. B. Campbell, K. J. Jarvi, R. C. Seymour, and J. A. Kalisch. 1994. Insect management guide for Nebraska corn and sorghum. Univ. Neb. Coop. Ext. Circ. 94-1509.

Received for publication 27 October 1997; accepted 16 September 1998 